ZOOLOGIA 28 (5): 653-657, October, 2011

doi: $10.1590 /$ S1984-46702011000500013

\title{
Species of fruit flies (Diptera: Tephritidae) in a transect of the Amazonian Rainforest in Oiapoque, Amapá, Brazil
}

\author{
Rose B. Rodrigues Trindade ${ }^{1} \&$ Manoel A. Uchôa ${ }^{1,2}$
}

\begin{abstract}
${ }^{1}$ Laboratório de Insetos Frugívoros, Faculdade de Ciências Biológicas e Ambientais, Universidade Federal da Grande Dourados. Rodovia Dourados-Itaum, km 12, Caixa Postal 241, Cidade Universitária, 79804-970 Dourados, MS, Brazil. 2 Corresponding author. E-mail: uchoa.manoel@gmail.com
\end{abstract}

\begin{abstract}
Species of fruit flies (Tephritidae) were surveyed in a transect of the Amazonian Rainforest in the district of Clevelândia do Norte, municipality of Oiapoque, state of Amapá, Brazil. This study describes the diversity of fruit fly species sampled inside this transect (2.2 linear km). Eleven McPhail traps were serviced weekly from June 2002 to June 2003. A total of 55 samples were obtained, totaling 125 specimens of Tephritidae. Anastrepha Schiner, 1868 was the most abundant and diverse genus, with 18 species caught. Two new species, A. oiapoquensis Norrbom \& Uchôa, 2011 and A. siculigera Norrbom \& Uchôa, 2011, were discovered in this survey. Anastrepha coronilli Carrejo \& González, 1993 $(n=40)$ was the most abundant species. Six species, Anastrepha amita Zucchi, 1979, A. duckei Lima, 1934, A. flavipennis Greene, 1934, A. minensis Lima, 1937, A. pseudoparallela (Loew, 1873), and A. submunda Lima, 1937, are recorded for the first time from Amapá. Three of them, A. minensis, A. pseudoparallela, and A. submunda, are reported for the first time from northern Brazil. This paper updates to 36 the number of frugivorous species of Tephritidae in Amapá.
\end{abstract}

KEY WORDS. Anastrepha; diversity; McPhail traps; northern Brazil.

The Amazon is the largest Rainforest in the world. In Brazil it occupies an area of approximately 5.5 million $\mathrm{km}^{2}$, representing about $50 \%$ of the Brazilian territory. It houses a rich plant diversity and a large number of native species of fruit trees, including various species of Anacardiaceae, Myrtaceae, and Sapotaceae (CAVAlCANTE 1991), which are considered potential host plants for the species of frugivorous Tephritoidea (ZucCHI 2008, UCHÔA \& NiCÁcIO 2010).

In the north region of Brazil, 60 species of Anastrepha have been recorded, representing $53.57 \%$ of the 112 species of the genus currently reported from the country (ZuCCHI 2008, NORRBOM \& UCHÔA 2011). In addition to the species of Anastrepha, two introduced species, Ceratitis capitata (Wiedemann, 1824) and Bactrocera carambolae Drew \& Hancock, 1994, also occur in Amapá (Silva \& Ronchi-Teles 2000, UchôA \& Nicácio 2010).

The knowledge of the diversity, as well as the time of population outbreaks of a particular species of Tephritoidea with economic importance, is a prerequisite for the establishment of integrated pest management strategies of fruit fly populations (Ronchi-Teles \& Silva 2005). It appears to us that there are new species of Anastrepha in the Oiapoque region and some fruit fly species not yet recorded from northern Brazil or even from the country.

This paper describes the diversity of tephritid species along a transect in the Amazonian Rainforest at the municipality of Oiapoque, state of Amapá, Brazil, provides new records, and suggests ecological patterns for the populations.

\section{MATERIAL AND METHODS}

This study was carried out in the district of Clevelândia do Norte $\left(30^{\circ} 49^{\prime} 35^{\prime \prime} \mathrm{N}, 51^{\circ} 51^{\prime} 39^{\prime \prime} \mathrm{W}\right)$, about $2.5 \mathrm{~km}$ from the southern margin of the Oiapoque River. This region is located about $5 \mathrm{~km}$ south of the city of Oiapoque, Amapá, in the border with French Guiana, and harbors primary Rainforests. The area sampled presents the characteristic vegetation of dense highlands forest (CAVAlCANTE 1991).

The climate is Ami type, according to Köppen's classification, with average annual temperature of $27^{\circ} \mathrm{C}$, relative humidity of $82 \%$, and annual rainfall greater than $3,000 \mathrm{~mm}$. The dry period occurs from September to November, and the rainy season extends from December to June (ANA 2004).

Eleven plastic McPhail traps were employed in the survey. All were baited with hydrolyzed corn protein $(5 \% \mathrm{v} / \mathrm{v})$ stabilized with borax ( $\mathrm{pH} 8.5$ to 9.0). The traps were placed on the tree branches, $1.60 \mathrm{~m}$ above the ground, approximately $200 \mathrm{~m}$ apart from one another, along a linear $2.2 \mathrm{~km}$ transect. The first trap was placed at $30^{\circ} 48^{\prime} 56^{\prime \prime} \mathrm{N}, 51^{\circ} 51^{\prime} 46^{\prime \prime} \mathrm{W}$ and the last trap at $30^{\circ} 47^{\prime} 58^{\prime \prime} \mathrm{N}, 51^{\circ} 51^{\prime} 53^{\prime \prime} \mathrm{W}$. Each trap was inspected weekly from June 15, 2002 to June 28, 2003 to remove the trapped insects and renew the bait. Because the transect area was homogenous, all flies sampled weekly from the 11 traps were put together, totaling 55 samples.

The collected fruit flies were stored in vials with $70 \%$ ethanol, transported to the Laboratório de Insetos Frugívoros, 
Faculdade de Ciências Biológicas e Ambientais (FCBA), Universidade Federal da Grande Dourados (UFGD), and identified by M.A. Uchôa, using taxonomic keys and species descriptions (Stone 1942, Steyskal 1977, Zucchi 2000, Norrbom 1997, Norrbom \& Korytкоwsкi 2009). Voucher specimens were deposited in the Entomological Collection of the Museu da Biodiversidade, (FCBA, UFGD), Dourados, state of Mato Grosso do Sul.

Our data on the fruit flies included the numbers of females only, because keys are not yet available for the identification of Anastrepha males.

\section{RESULTS}

A total of 125 adults in three Tephritidae genera were collected: Anastrepha Schiner, 1868, Blepharoneura Loew, 1873, and Tomoplagia Coquillett, 1910. Our sample included 30 males and 93 females of Anastrepha, a single male of Blepharoneura, and another of Tomoplagia (Tab. I).

In this survey, 18 Anastrepha species were sampled. Of those, six were new records for the state of Amapá, three had not been previously recorded from northern Brazil, and two were new species, which have been described elsewhere (Norrbom \& UCHÔA 2011) (Tab. I).

This paper includes, in addition to original data, compilation records updating to 34 the number of Anastrepha species reported from Amapá (Zucchi 2008, Silva et al. 2007, Jesus et al. 2008, NовRвом \& Uсноिа 2011), and a total of 36 species of fruit flies, because Ceratitis capitata (Wiedemann, 1824) and Bactrocera carambolae Drew \& Hancock, 1994 are also present in the state (Fig. 1).

Anastrepha presented the highest richness $(\mathrm{S}=18)$ and abundance (98.4\%). It was represented by four species groups according to the classification of Norrbom et al. (1999). The fraterculus group was represented by 11 species: A. amita Zucchi, 1979, A. coronilli Carrejo \& González, 1993, A. distincta Greene, 1934, A. duckei Lima, 1934, A. flavipennis Greene, 1934, A. fraterculus (Wiedemann, 1830), A. furcata Lima, 1934, A. minensis Lima, 1937, A. mixta Zucchi, 1979, A. obliqua (Macquart, 1835), and $A$. sororcula Zucchi, 1979 ; the mucronota group by $A$. submunda Lima, 1937; the pseudoparallela group by $A$. binodosa

Table I. Species of Tephritidae from Clevelândia do Norte, municipality of Oiapoque, Amapá: monthly capture, abundance, and frequencies (absolute and relative) (June 2002 to June 2003).

\begin{tabular}{|c|c|c|c|c|c|c|c|c|c|c|c|c|c|c|c|}
\hline \multirow{2}{*}{ Species/species group } & \multicolumn{13}{|c|}{ Months from 2002 to 2003} & \multicolumn{2}{|c|}{ Frequencies } \\
\hline & Jun & Jul & Aug & Sep & Oct & Nov & Dec & Jan & Feb & Mar & Apr & May & Jun & Absolute & Relative (\%) \\
\hline Anastrepha amita Zucchi F* & & & & & & & 1 & & & & & & & 1 & 0.8 \\
\hline A. binodosa Stone $\mathrm{P}$ & & 2 & & & & & & & & & & & & 2 & 1.6 \\
\hline A. coronilli Carrejo \& González $\mathrm{F}$ & & 7 & 16 & 10 & 4 & 1 & & & 1 & & 1 & & & 40 & 32.0 \\
\hline A. dissimilis Stone $\mathrm{P}$ & & & & & 1 & 1 & & 1 & & & & & & 3 & 2.4 \\
\hline A. distincta Greene F & & & & & & & & & & 1 & 2 & & & 3 & 2.4 \\
\hline A. duckei Lima $\mathrm{F}^{*}$ & & & & & & 1 & & & & & & & & 1 & 0.8 \\
\hline A. flavipennis Greene $\mathrm{F}$ * & & & & 1 & & & & & & & & & & 1 & 0.8 \\
\hline A. fraterculus (Wiedemann) $\mathrm{F}$ & & & & & & 2 & & & & & & & & 2 & 1.6 \\
\hline A. furcata Lima $\mathrm{F}$ & & & & 1 & & & & & & 1 & & & & 2 & 1.6 \\
\hline A. minensis Lima $\mathrm{F}$ * & & & & & & & & 1 & & & & & & 1 & 0.8 \\
\hline A. mixta Zucchi $\mathrm{F}$ & & & & & 1 & 2 & 1 & & & & & & & 4 & 3.2 \\
\hline A. obliqua (Macquart) $\mathrm{F}$ & & & & & & & & & 1 & & & & & 1 & 0.8 \\
\hline A. oiapoquensis Norrbom \& Uchôa U & & & & & & 3 & & & & & & & & 3 & 2.4 \\
\hline A. pseudoparallela (Loew) $\mathrm{P}$ * & & & & 2 & & 1 & 1 & 3 & 1 & 1 & & & & 9 & 7.2 \\
\hline A. rafaeli Norrbom \& Korytkowski R & & & & & & 1 & & & & & & & & 1 & 0.8 \\
\hline A. siculigera Norrbom \& Uchôa U & & & & & & & & & & 1 & & & & 1 & 0.8 \\
\hline A. sororcula Zucchi $\mathrm{F}$ & & & & & & 2 & 1 & 2 & 1 & 4 & 6 & 1 & & 17 & 13.6 \\
\hline A. submunda Lima $\mathrm{M}$ * & & & & & & & & & & 1 & & & & 1 & 0.8 \\
\hline Anastrepha spp. (males) & & & 2 & 10 & 6 & 5 & & 1 & & 4 & 1 & 1 & & 30 & 24.0 \\
\hline Blepharoneura sp. & & & & & & & 1 & & & & & & & 1 & 0.8 \\
\hline Tomoplagia sp. & & & & & & & & & & & 1 & & & 1 & 0.8 \\
\hline Total of individuals & 0 & 2 & 9 & 30 & 18 & 22 & 6 & 8 & 3 & 14 & 10 & 3 & 0 & 125 & 100.0 \\
\hline
\end{tabular}

Legend for species groups: (F) fraterculus group, (M) mucronota group, (P) pseudoparallela group, (R) robusta group, (U) unplaced. * New record for Amapá. 


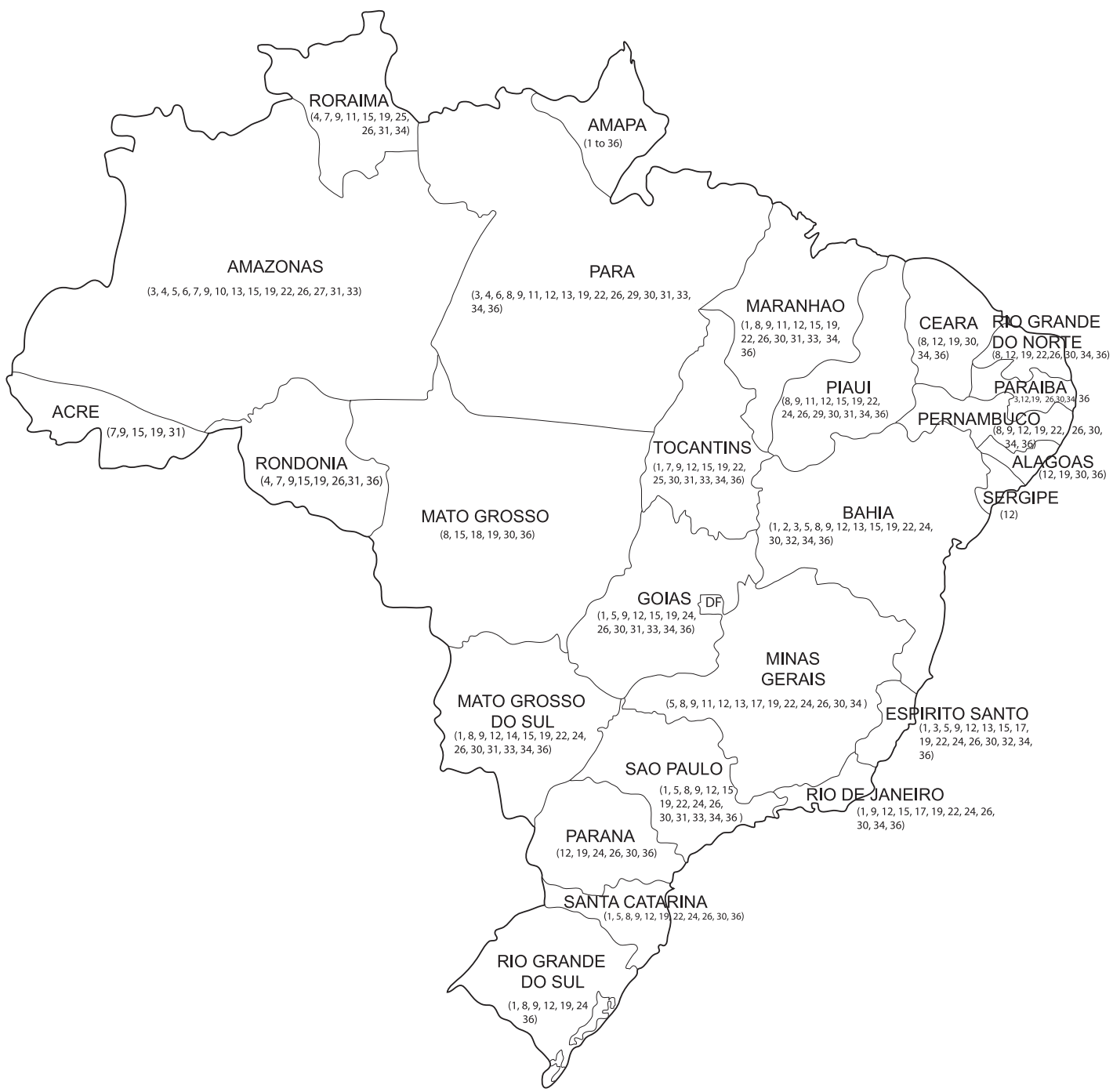

Figure 1. Geographic distribution in Brazil of the Anastrepha species reported from Amapá, based on the present study (species 1, 6, 7, $8,9,10,11,12,13,17,18,19,20,24,25,28,30,32)$ and on previous records: Silva et al. (2007), species 3, 4, 15, 16, 22, 26, 31, 33, 34, 35; Jesus et al. (2008), species 21; ZucCHI (2008), species 2, 5, 14, 23, 27, 29; UCHÔA \& NicácIo (2010), species 36; and Pereira et al. (2010), species 7 and 9 from states of Acre and Rondônia. Legend: ( $\left.{ }^{*} 1\right)$ Anastrepha amita, (2) A. anomala, (3) A. antunesi, (4) A. atrigona, (5) A. bahiensis, (6) A. binodosa, (7) A. coronilli, (8) A. dissimilis, (9) A. distincta, (*10) A. duckei, ( $\left.{ }^{*} 11\right)$ A. flavipennis, (12) A. fraterculus, (13) A. furcata, (14) A. hastata, (15) A. leptozona, (16) A. limae, (*17) A. minensis, (18) A. mixta, (19) A. obliqua, (20) A. oiapoquensis, (21) A. parishi, (22) A. pickeli, (23) A. pseudanomala, ( $\left.{ }^{*} 24\right)$ A. pseudoparallela, (25) A. rafaeli, 26. A. serpentina, 27. A. shannoni, (28) A. siculigera, (29) A. sodalis, (30) A. sororcula, (31) A. striata, (*32) A. submunda, (33) A. turpiniae, (34) A. zenildae, (35) Bactrocera carambolae, (36) Ceratitis capitata. *New records for the state of Amapá.

Stone, 1942, A. dissimilis Stone, 1942, and A. pseudoparallela (Loew, 1873); and the robusta group by A. rafaeli Norrbom \& Korytkowski, 2009. The recently described species, A. oiapoquensis Norrbom \& Uchôa, 2011 and A. siculigera Norrbom \& Uchôa, 2011, are still not classified phylogenetically into species groups. Anastrepha coronilli was the most frequent and abundant (32\%) species of fruit fly in this survey (Tab. I). In Brazil, this species is restricted to the North, with reports from the states of Acre, Amapá, Amazonas, Rondônia, Roraima, and Tocantins (BomfiM et al. 2007, Zucchi 2008, Pereira et al. 2010) (Fig. 1). The second most frequent species was $A$. sororcula $(13.6 \%)$, followed by $A$. pseudoparallela (7.2\%) (sensu NorRBom 1997) (Tab. I). 


\section{DISCUSSION}

Previous studies recorded the occurrence of 25 Anastrepha species in the state of Amapá. Silva et al. (2007) presented a list of 14 Anastrepha species: A. antunesi Lima, 1938, A. atrigona Hendel, 1914, A. coronilli Carrejo \& González, 1993, A. distincta Greene, 1934, A. fraterculus (Wiedemann, 1830), A. leptozona Hendel, 1914, A. limae Stone, 1942, A. obliqua (Macquart, 1835), A. pickeli Lima, 1934, A. serpentina (Wiedemann, 1830), A. sororcula Zucchi, 1979, A. striata Schiner, 1868, A. turpiniae Stone, 1942, and A. zenildae Zucchi, 1979. Zucchi (2008) added 10 other records: A. anomala Stone, 1942, A. bahiensis Lima, 1937, A. binodosa Stone, 1942, A. dissimilis Stone, 1942, A. furcata Lima, 1934, A. hastata Stone, 1942, A. mixta Zucchi, 1979, A. pseudanomala Norrbom, 2002, A. shannoni Stone, 1942, and A. sodalis Stone, 1942. Jesus et al. (2008) reported the occurrence of $A$. parishi Stone, 1942.

Twelve of the 18 Anastrepha species caught in the traps in this research had been previously reported from Amapá (SIIVA et al. 2007, Zucchi 2008, Jesus et al. 2008, Norrbom \& UсhÔA 2011). However, six others (A. amita, A. duckei, A. flavipennis, A. minensis, A. pseudoparallela, and $A$. submunda) are new records. Recently, Norrbom \& UchôA (2011) described $A$. oiapoquensis and $A$. siculigera, and reported the occurrence of A. rafaeli in Oiapoque, Amapá (Tab. I). The following species are also reported for the first time from northern Brazil: $A$. minensis, A. pseudoparallela, and A. submunda (Tab. I).

Our findings extend the range of $A$. pseudoparallela to all regions of Brazil. Regarding the species of fruit flies recorded from Amapá, A. obliqua, A. sororcula, A. fraterculus, A. serpentina, A. distincta, A. zenildae, and C. capitata are the most widespread in Brazil. Anastrepha obliqua occurs in all five regions and in all states, except in the state of Sergipe, where a survey has not been conducted; $A$. sororcula occurs in all regions and 22 states; A. fraterculus and C. capitata are reported in all regions and 21 states, followed by $A$. serpentina, found in all regions and 19 states; $A$. distincta is known from all regions and 18 states; $A$. zenildae is known from all regions (except South) and 17 states (Fig. 1).

Formerly, A. minensis had been reported only from southeastern Brazil. The record of this species from northern Brazil is probably due to the fact that in these two regions there are remnants of Atlantic and Amazonian forests, respectively, where species of Myrciaria (Myrtaceae) are found. Species of Myrtaceae produce the preferred host fruit of Anastrepha species in the fraterculus group (Silva et al. 2010), and Myrciaria species are considered natural hosts of A. minensis (Zucchr 2008).

Anastrepha obliqua was rarely found in the traps. Although it is considered one of the most abundant species of fruit flies in orchards in northern Brazil (SILVA \& RonChI-Teles 2000, RonCHITeles \& Silva 2005, Silva et al. 2007, Bomfim et al. 2007), its low abundance in native forests was expected. Many species of frugivorous flies usually occur in natural environments, but represented by few individuals. In native forests, there is greater diversity of hosts and natural enemies, with a tendency of having greater evenness among the different co-occurring species of fruit flies (Вомғiм et al. 2007, Costa et al. 2009). Conversely, in fruit crop ecosystems, where host plant diversity is low and species of polyphagous fruit flies such as A. obliqua are favored, the opposite situation is found (SILVA et al. 2007, 2010). The latter authors examined fruit samples from orchards in several localities from northern and northeastern Brazil and found that A. obliqua was one of the most abundant and polyphagous species of fruit flies attacking fruits.

Although in this study 11 traps were used in only one year of survey, and a small transect of native forest (2.2 linear $\mathrm{km}$ ) was sampled, the diversity of fruit flies found ( $\mathrm{S}=18$ ) can be considered similar to that in other surveys carried out in Brazil. For instance, GARCIA et al. (2003), in two years of sampling with 48 traps, captured 14 Anastrepha species in the western portion of the state of Santa Catarina. URAmoto et al. (2005), in one year and using 84 traps, sampled 18 Anastrepha species in Piracicaba, state of São Paulo. CANESIN \& UCHÔA (2007), during one year and using 11 McPhail traps in a fragment of native semideciduous forest in the south of the state of Mato Grosso do Sul, sampled 13 Anastrepha species.

It is known that in primary forests (e.g., Amazonian Rainforest) the stability and heterogeneity of the vegetation are higher than in secondary forests and this favors species richness in groups of phytophagous insects such as Anastrepha (Bомғім et al. 2007). In this genus, species richness tends to agree with the diversity of plant species. The diversity of fruit trees in a natural forest increases the likelihood of occurrence of monophagous species of fruit flies (sensu AluJA \& MANGan 2008) and, therefore, increases the probability of a greater diversity of Tephritoidea in the ecosystem. This pattern is also common in other groups of arthropods (Altieri \& Letourneau 1984, Andow 1991, BRAgança et al. 1998).

A future and important step of our research will be to investigate the host fruits of each captured species of fruit fly, in order better understand the relationships among them and the diversity of their host plants in the Amazonian Rainforest.

\section{ACKNOWLEDGMENTS}

We thank Coordenação de Aperfeiçoamento de Pessoal de Nível Superior (CAPES) for the Magister Scientiae grant to RBRT and for the postdoctoral fellowship (process 1030/09-4 BEX) to M.A. Uchôa. We also thank Allen L. Norrbom (Systematic Entomology Laboratory-USDA, Washington-D.C.) and three anonymous reviewers for their comments on the manuscript.

\section{LITERATURE CITED}

Altieri, M.A. \& D.K. Letourneau. 1984. Vegetation diversity and insect pest outbreaks. CRC Critical Review in Plant Sciences 2: 131-169. 
Aluja, M. \& R.L.Mangan. 2008. Fruit fly (Diptera: Tephritidae) host status determination: critical conceptual, methodological, and regulatory considerations. Annual Review of Entomology 53: 273-502.

ANA.2004 Totais pluviométricos de longo período na Sub-bacia 30 (do rio Oiapoque ao rio Araguari). Agência Nacional de Águas, available online at: http://www.ana.gov.br/gestao RecHidricos/InfoHidrologicas [Accessed: 17/IX/2008]

AnDow, D.A. 1991. Vegetational diversity and arthropod population response. Annual Review of Entomology 36: 561-586.

BRAGANÇA, M.A.L.; O.D. SouZA \& J.C. ZanunCIO. 1998. Environmental heterogeneity as a strategy for pest management in Eucalyptus plantations. Forest Ecology and Management 102: 9-12.

Bomfim, D.A.; M. A. UchôA \& M.A. L. Bragança. 2007. Biodiversidade de moscas-das-frutas (Diptera, Tephritoidea) em matas nativas e pomares domésticos de dois municípios do Estado do Tocantins, Brasil. Revista Brasileira de Entomologia 51: 217-223.

Canesin, A. \& M.A. UChôA. 2007. Análise faunística e flutuação populacional de moscas-das-frutas (Diptera, Tephritidae) em um fragmento de floresta semidecídua em Dourados, Mato Grosso do Sul. Revista Brasileira de Zoologia 24: 185-190.

Cavalcante, P.B. 1991. Frutas comestíveis da Amazônia. Belém, Edições CEJUP, Museu Paraense Emílio Goeldi, $5^{\text {th }}$ ed., 279p.

Costa, S.G.M.; R.B. Querino; B. Ronchi-Teles; M.A.M. PenteadoDiAs \& R.A. ZuCchI. 2009. Parasitoid diversity (Hymenoptera: Braconidae and Figitidae) on frugivorous larvae (Diptera: Tephritidae and Lonchaeidae) at Adolpho Duke Forest Reserve, Central Amazon Region, Manaus, Brazil. Brazilian Journal of Biology 69: 363-370.

GarCia, F.R.M.; J.V. Campos \& E. Corseull. 2003. Análise faunística de espécies de moscas-das-frutas (Diptera: Tephritidae) na região oeste de Santa Catarina. Neotropical Entomology 32: 421-426.

Jesus, C.R.; N.M. Oliveira; M.F. Silva-Filho; R.A. Silva \& R.A. Zucchi. 2008. First record of Anastrepha parishi Stone (Diptera, Tephritidae) and its host in Brazil. Revista Brasileira de Entomologia 52: 135-136.

Norrbom, A.L. 1997. Revision of the Anastrepha benjamini species group and the A. pallidipennis complex (Diptera: Tephritidae). Insecta Mundi 11: 141-157.

Norrbom, A.L. \& C.A. Korytкowski. 2009. A revision of the Anastrepha robusta species group (Diptera: Tephritidae). Zootaxa 2182: 1-91.

Norrbom, A.L. \& M.A. UchôA. 2011. New species and records of Anastrepha (Diptera: Tephritidae) from Brazil. Zootaxa 2835: 61-67.

Norrbom, A.L.; R.A. Zucchi \& V. Hernández-Ortiz. 1999. Phylogeny of the genera Anastrepha and Toxotripana (Trypetinae:
Toxotripanini) based on morphology, p. 299-342. In: M. AlujA \& A.L. Norrbom (Eds). Fruit Flies (Tephritidae): Phylogeny and evolution of behavior. Boca Raton, CRC Press, 944p.

Pereira, J.D.B.; D.P. Buriti; W.P. Lemos; W.R. Silva \& R.A. Silva. 2010. Espécies de Anastrepha Schiner (Diptera: Tephritidae), seus hospedeiros e parasitóides nos Estados do Acre e Rondônia, Brasil. Biota Neotropica 10: 441-446.

Ronchi-Teles, B. \& N.M. Silva. 2005. Flutuação populacional de espécies de Anastrepha Schiner (Diptera: Tephritidae) na região de Manaus, AM. Neotropical Entomology 34: 733-741.

Silva, J.G.; V.S. Dutra; M.S. Santos; N.M.O. Silva; D.B. Vidal; R.A. Nink; J.A. Guimarães \& E.L. Araujo. 2010. Diversity of Anastrepha spp. (Diptera: Tephritidae) and associated Braconid parasitoids from native and exotic hosts in Southeastern Bahia, Brazil. Environmental Entomology 39: 1457-1465.

Silva, N.M. \& B. Ronchi-Teles. 2000. Moscas-das-frutas nos estados brasileiros: Amapá, Amazonas, Pará, Rondônia e Roraima, p. 203-209. In: A. MalaVAsi \& R.A. Zucchi (Eds). Mosca-dasfrutas de importância econômica no Brasil: Conhecimento básico e aplicado. Ribeirão Preto, FAPESP, Holos, 327p.

Silva, R.A.; S.L.O. Xavier; M.F. Souza Filho; W.R. Silva; D.B. NasciMENTo \& E.G. Deus. 2007. Frutíferas hospedeiras e parasitóides (Hym., Braconidae) de Anastrepha spp. (Dip., Tephritidae) na Ilha de Santana, Estado do Amapá, Brasil. Arquivos do Instituto Biológico de São Paulo 74: 153-156.

Steyskal, G.C. 1977. Pictorial key to species of the genus Anastrepha (Diptera: Tephritidae). Washington, D.C., Entomological Society of Washington, 35p.

STONe, A. 1942. The fruit flies of the genus Anastrepha. Washington, D.C., United States Department of Agriculture, Miscellaneous Publication 439, 112p.

UChôA, M.A. \& J.N. Nić́cıo. 2010. New records of Neotropical fruit flies (Tephritidae), lance flies (Lonchaeidae) (Diptera: Tephritoidea), and their host plants in the South Pantanal and adjacent areas, Brazil. Annals of the Entomological Society of America 103: 723-733.

Uramoto, K.; J.M.M. Walder \& R.A. Zucchi. 2005. Análise quantitativa e distribuição de populações de espécies de Anastrepha (Diptera: Tephritidae) no Campus Luiz de Queiroz, Piracicaba, SP. Neotropical Entomology 34: 33-39.

Zucchi, R.A. 2000. Taxonomia, p.13-24. In: A. Malavasi \& R.A. ZuCCHI (Eds). Mosca-das-frutas de importância econômica no Brasil: Conhecimento básico e aplicado. Ribeirão Preto, FAPESP, Holos, 327p.

Zucchi, R.A. 2008. Fruit flies in Brazil - Anastrepha species their host plants and parasitoids. Available online at: www.lea.esalq.usp.br/ anastrepha [Accessed: 26/V/2011]

Submitted: 17.I.2011; Accepted: 17.VI.2011.

Editorial responsibility: Gabriel L.F. Mejdalani 